\title{
Market Trend and Current Status of the Research and Development of Antibody-Drug Conjugates
}

\author{
Sun-II Kwon ${ }^{\dagger}, *$ \\ Department of Biomedical Laboratory Science, Deagu Health Science University, Daegu 41453, Korea
}

\begin{abstract}
Antibody-drug conjugates (ADCs) are drawing much interest due to its great potential to be one of the important options in cancer treatments. ADCs are acting like a magic bullet which delivers cytotoxic drugs specifically to cancerous cells throughout the body, thus attacks these cells, while not harming healthy cells. ADCs are complex molecules that are composed of an antibody having targeting capability and linked-payload or cytotoxic drug killing cancerous cells. The key factors of the success in the development of ADC are selection of appropriate antibody, cytotoxic payload and linker for conjugation. Recently there was considerable progress in ADCs development, and a large number of ADCs gained US FDA approval. About 80 new ADCs are under active clinical studies. In this review we present a brief introduction of the US-FDA approved ADCs and global situation in the clinical studies of ADC pipelines. We address an overview on each component of an ADC design such as target antigens, payloads, linkers, conjugation methods, drug antibody ratio. In addition, we discuss on the trend of $\mathrm{ADC}$ market where global big pharmas and domestic biopharmaceutical companies are competing to develop safer and more effective ADCs.
\end{abstract}

Key Words: ADC, Antibody, Drug, Conjugate, Linker, Payload, Anti-cancer, Clinical

\section{1. 서론}

의약품 시장에서는 합성의약품과 바이오의약품이 두 축 을 이룬다. 과거에는 합성의약품이 주류를 이루었으나 이 제 바이오의약품이 대세이다. 바이오의약품은 그 비중이 증가하는 추세인데 2017년에는 세계 10대 블록버스터 중 8개를 차지하게 되었다(Urquhart, 2018). 2019년에는 매출액 세계 상위 100 대 의약품 중 바이오의약품의 비중이 $71 \%$ 를 넘어서 합성의약품 매출액의 두 배를 넘었다(KoBIA, 2021). 초창기에 상용화된 바이오의약품은 항체의약품으 로 단일클론항체(monoclonal antibody; $\mathrm{mAb}$ )가 주를 이루 었다. 기존 항체의약품에서 안전성과 유효성을 개선한 혁
신 항체의약품이 많이 연구되고 있다. 혁신 항체의약품으 로는 단일클론항체를 개선한 바이오베터(biobetter), 항체 를 작게 만든 항체 절편(antibody fragment), 두 가지 항원 과 동시에 결합하는 이중 항체(bispecific antibody), 약물과 항체를 결합시킨 항체-약물 접합체(antibody-drug conjugate; $\mathrm{ADC}$, 이하 $\mathrm{ADC}$ ) 등이 있다.

이중 $\mathrm{ADC}$ 는 세포독성약물의 효력을 단독 약물로 사용 할 때보다 안전하게 향상시킬 수 있는 잠재력으로 주목 받고 있다. $\mathrm{ADC}$ 는 항체에 약물을 달아서 항체가 특이적 으로 병소부위만 타겟팅하도록 하여 약물이 정상조직에 는 전달되지 않고 병소부위에만 전달되도록 한다. 암세포 의 경우 암세포 표면에 발현된 특정 항원에 특이적으로 결합하는 항체를 사용하여 독성이 강한 약물을 암세포에

Received: August 18, 2021 / Revised: September 17, 2021 / Accepted: September 27, 2021

* Professor.

${ }^{\dagger}$ Corresponding author: Sun-Il Kwon. Department of Biomedical Laboratory Science, Deagu Health Science University, Youngsong-ro 15 (Taejeon-dong), Buk-ku, Daegu 41453, Korea.

Tel: +82-53-320-1302, Fax:+82-53-320-1450, e-mail: psikwon@dhc.ac.kr

(C) The Korean Society for Biomedical Laboratory Sciences. All rights reserved.

(C) This is an Open Access article distributed under the terms of the Creative Commons Attribution Non-Commercial License (http://creativecommons.org/licenses/by-nc/3.0/) which permits unrestricted non-commercial use, distribution, and reproduction in any medium, provided the original work is properly cited. 
특이적으로 전달하여 암세포만 사멸시키게 한다. 그동안 독성이 높고 그에 따라 치료역이 좁은 것이 문제점으로 지적되어 왔으나 최근에는 독성을 줄인 차세대 $\mathrm{ADC}$ 가 등장하여 $\mathrm{ADC}$ 는 바이오의약품 시장의 주류 트렌드가 되 고 있다.

2000년도에 미국 Wyeth(현 화이자(Pfizer)로 합병)사에서 마일로타그(Mylotarg $\left.{ }^{\circledR}\right)$ 로 최초의 $\mathrm{ADC}$ 를 허가를 받은 이 래로 11 개의 $\mathrm{ADC}$ 가 미국 식품의약국(U.S. Food and Drug Administration, US FDA)에서 승인을 받았는데, 근래에 들 어서 2019년에는 패드세브(Padcev $\left.{ }^{\circledR}\right)$, 폴라이비(Polivy $\left.{ }^{\circledR}\right)$, 엔허투(Enhertu $\left.{ }^{\circledR}\right)$ 가 2020년에는 트로델비(Trodelvy $\left.{ }^{\circledR}\right)$, 블렌 렙(Blenrep $\left.{ }^{\circledR}\right)$ 이 2021년에는 진론타 $\left(\right.$ Zylonta $\left.^{\circledR}\right)$ 가 연이어 승 인을 받아서 $\mathrm{ADC}$ 임상연구에서 큰 결실을 맺고 있다. 또한 글로벌 빅파마 간의 고가의 딜이 $\mathrm{ADC}$ 파이프라인에 서 나오고 있다. 현재 $\mathrm{ADC}$ 는 세계적으로 약 80 여개 품목 에 300건이 넘는 임상시험이 진행되고 있어서 밝은 미래 가 기대되고 있다. 바이오의약품 시장에서 $\mathrm{ADC}$ 가 차지하 는 비중도 더욱 커질 것으로 생각된다. 본고에서는 $\mathrm{ADC}$ 치료제 연구 개발의 현황과 시장 동향에 대하여 고찰해 보고자 한다.

\section{2. $\mathrm{ADC}$ 의 등장 배경}

암의 치료에는 면역항암제가 많이 쓰이고 있지만 아직 도 전통적인 화학요법제가 중요한 역할을 하고 있다. 화 학요법 항암제는 주로 일반세포와 암세포를 구분하기 위 하여 세포주기의 차이를 이용한다. 화학요법제는 치료효 과를 얻기 위하여 보통 최대 허용량(maximum tolerated dose) 근처에서 사용된다. 화학요법제는 암세포가 표적이 지만, 정상세포와 암세포의 구분이 없이 단지 빠르게 분 열하는 세포를 죽일 뿐이므로 전신독성과 세포독성을 피 하기 어렵다. 따라서 화학요법제인 세포독성 약물을 암세 포에만 타겟팅하여 암세포만 특이적으로 사멸시키는 방 법이 필요하다.

치료용 단일클론항체는 종양세포의 표면에 존재하는 항 원에 특이적으로 결합하여 세포살상효과를 일으킨다. 종 양세포에만 결합하므로 비특이적인 전신독성 부담을 줄 여준다. 치료용 항체는 화학요법제보다 유리한 장점이 있 지만 종양 특이 항체 중 소수의 항체만 암치료용으로 사 용된다. 상당수의 종양 특이 항체는 항체만으로 암세포를 효과적으로 죽이지 못하기 때문이다.

강력한 살상능력을 가진 화학요법제와 암세포에만 타

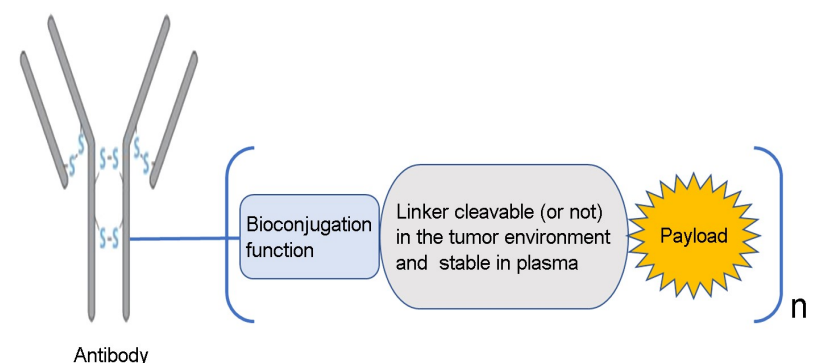

Fig. 1. The structure of antibody-drug conjugates. $n=$ DAR (drugto-antibody ratio) (modified from Joubert et al., 2020).

겟팅을 하는 특이성을 가진 항체를 결합시킬 경우 치료 효과를 높일 수 있다. 이러한 기대와 희망으로 탄생한 것이 항체와 화학요법제를 결합시킨 항체-약물 중합체 (antibody-drug conjugate, ADC)이다(Hasan et al., 2018).

\section{ADC 작동원리}

항체는 항원에 대하여 결합 친화력과 결합 특이성을 가 지고 있다. 이를 이용하여 표적으로 정확하게 안내하는 항체에 암세포와 같은 표적세포를 파괴할 수 있는 세포 독성약물(cytotoxic drugs, payload)을 단 것이 $\mathrm{ADC}$ 이다. $\mathrm{ADC}$ 를 만들 때에는 이 두 성분을 접합(conjugation)시키 는 링커(linker)까지 포함하여 모두 세 가지 요소가 필요 하다(Fig. 1) (Su and Zhang, 2021).

$\mathrm{ADC}$ 가 작동하려면 $\mathrm{ADC}$ 가 표적세포 내로 진입하여야 한다. 암세포와 같은 표적세포의 표면에 발현된 특정 항 원에 $\mathrm{ADC}$ 의 항체가 특이적으로 결합된 다음 세포막의 클라트린 피복 소공(clathrin-coated pit) 작동기전으로 표적 세포 안으로 들어간다.

세포 내로 함입된 $\mathrm{ADC}$ 는 클라트린에서 분리되고, 세 포 내에서 다른 소포체(vesicles)와 융합된 다음, 엔도좀리소좀(endosome-lysosome) 경로를 따라가게 된다. 엔도좀 에 도달한 다음 이곳의 특이적인 종양세포 내부 환경의 특정 요소에 의해 항체에서 약물이 분리된다. 항체에서 떨어져 독립한 자유로운 세포독성약물은 리소좀 막을 관 통하여 세포질로 가게 된다. 활성화된 약물은 주변에 있 는 자기 자신의 분자 타겟에 결합함으로써 약리효과를 발 휘하여 종양세포의 세포주기를 정지시키고 세포사멸을 유 도하여 암세포를 죽이게 된다(Hammood et al., 2021).

이러한 활동 가운데에서 일부의 세포독성약물은 수동 적으로 확산되거나, 능동적으로 수송되거나, 혹은 죽은 
Table 1. US FDA-approved ADCs

\begin{tabular}{|c|c|c|c|c|c|}
\hline Drug & Maker & Condition & $\begin{array}{l}\text { Trade } \\
\text { name }\end{array}$ & Target & $\begin{array}{l}\text { Approval } \\
\text { year }\end{array}$ \\
\hline $\begin{array}{l}\text { Gemtuzumab } \\
\text { ozogamicin }\end{array}$ & Pfizer/Wyeth & Relapsed acute myelogenous leukemia (AML) & Mylotarg & CD33 & $2017 ; 2000$ \\
\hline $\begin{array}{l}\text { Brentuximab } \\
\text { vedotin }\end{array}$ & $\begin{array}{l}\text { Seattle Genetics, } \\
\text { Millennium/Takeda }\end{array}$ & Relapsed HL and relapsed sALCL & Adcetris & CD30 & 2011 \\
\hline $\begin{array}{l}\text { Trastuzumab } \\
\text { emtansine }\end{array}$ & Genentech, Roche & $\begin{array}{l}\text { HER2-positive metastatic breast cancer (mBC) } \\
\text { following treatment with trastuzumab and a } \\
\text { maytansinoid }\end{array}$ & Kadcyla & HER2 & 2013 \\
\hline $\begin{array}{l}\text { Inotuzumab } \\
\text { ozogamicin }\end{array}$ & Pfizer/Wyeth & $\begin{array}{l}\text { Relapsed or refractory CD22-positive B-cell } \\
\text { precursor acute lymphoblastic leukemia }\end{array}$ & Besponsa & $\mathrm{CD} 22$ & 2017 \\
\hline $\begin{array}{l}\text { Moxetumomab } \\
\text { pasudotox }\end{array}$ & Astrazeneca & $\begin{array}{l}\text { Adults with relapsed or refractory hairy cell } \\
\text { leukemia (HCL) }\end{array}$ & Lumoxiti & $\mathrm{CD} 22$ & 2018 \\
\hline $\begin{array}{l}\text { Polatuzumab } \\
\text { vedotin-piiq }\end{array}$ & Genentech, Roche & $\begin{array}{l}\text { Relapsed or refractory (R/R) diffuse large } \\
\text { B-cell lymphoma (DLBCL) }\end{array}$ & Polivy & CD79 & 2019 \\
\hline $\begin{array}{l}\text { Enfortumab } \\
\text { vedotin }\end{array}$ & $\begin{array}{l}\text { Astellas/Seattle } \\
\text { Genetics }\end{array}$ & $\begin{array}{l}\text { Adult patients with locally advanced or metastatic } \\
\text { urothelial cancer who have received a PD-1 or } \\
\text { PD-L1 inhibitor, and a Pt-containing therapy }\end{array}$ & Padcev & Nectin-4 & 2019 \\
\hline $\begin{array}{l}\text { Trastuzumab } \\
\text { deruxtecan }\end{array}$ & $\begin{array}{l}\text { AstraZeneca/ } \\
\text { Daiichi Sankyo }\end{array}$ & $\begin{array}{l}\text { Adult patients with unresectable or metastatic } \\
\text { HER2-positive breast cancer who have received } \\
\text { two or more prior anti-HER2 based regimens }\end{array}$ & Enhertu & HER2 & 2019 \\
\hline $\begin{array}{l}\text { Sacituzumab } \\
\text { govitecan }\end{array}$ & Immunomedics & $\begin{array}{l}\text { Adult patients with metastatic triple-negative } \\
\text { breast cancer (mTNBC) who have received at } \\
\text { least two prior therapies for patients with } \\
\text { relapsed or refractory metastatic disease }\end{array}$ & Trodelvy & Trop-2 & 2020 \\
\hline $\begin{array}{l}\text { Belantamab } \\
\text { mafodotin-blmf }\end{array}$ & $\begin{array}{l}\text { GlaxoSmithKline } \\
\text { (GSK) }\end{array}$ & $\begin{array}{l}\text { Adult patients with relapsed or refractory } \\
\text { multiple myeloma }\end{array}$ & Blenrep & BCMA & 2020 \\
\hline $\begin{array}{l}\text { Loncastuximab } \\
\text { tesirine-lpyl }\end{array}$ & ADC Therapeutics & Large B-cell lymphoma & Zynlonta & CD19 & 2021 \\
\hline
\end{tabular}

Source:

Biochempeg Worldwide PEG Supplier home page (https://www.biochempeg.com/article/74.html) (Biochempeg, 2021)

세포를 통해 세포 밖으로 빠져나가게 된다. 이렇게 주변 으로 퍼진 약물이 세포막으로 투과되면 인접세포에 들어 가 주변세포도 같이 죽이는 주변세포살상 작용이 발생하 기도 한다. 상당수의 암 특이적 항원은 암세포의 표면에 제한적으로 발현된다. 이러한 경우 $\mathrm{ADC}$ 로 충분한 양의 세포독성약물을 암세포 내로 전달하는 것이 쉽지 않아서 대안으로 독소의 강도를 높인다. $\mathrm{ADC}$ 에 결합되는 세포독 성약물로는 일반적인 항암제보다 강한 약물이 사용되었 다(Kim, 2011; Bae, 2019).

\section{US FDA에서 승인된 $\mathrm{ADC}$}

최초로 US FDA에서 승인된 $\mathrm{ADC}$ 는 Wyeth의 마일로 타그(Mylotarg $\left.{ }^{\circledR}\right)$ 인데 2000년에 승인되었다. 마일로타그는 2010년에 안전성에 대한 우려로 2010년 자발적으로 승인
철회되었다가 2017년에 재승인 되었다. 지난 20년 간 바 이오제약업계가 $\mathrm{ADC}$ 개발 분야에 경험과 기술을 축적하 면서, 그 노력이 새로운 $\mathrm{ADC}$ 제품의 승인이라는 성과로 나타나고 있다. 2019년 이후 다양한 $\mathrm{ADC}$ 치료제가 줄지 어 미국 FDA에서 승인되고 있다. Table 1은 지금까지 US $\mathrm{FDA}$ 에서 시판 승인된 11 가지 $\mathrm{ADC}$ 제품을 종합하여 보 여준다(Table 1). US FDA 승인을 획득한 대표적인 $\mathrm{ADC}$ 를 세대별로 나누어 살펴보겠다.

\section{4-1. 1세대 절단 링커 $\mathrm{ADC}$; 마일로타그(Mylotarg ${ }^{\circledR}$ ), 베스폰사(Besponsa ${ }^{\circledR}$ )}

마일로타그는 2000년에 급성골수구성백혈병(acute myeloid leukemia, AML)을 적응증으로 승인되었다. 마일로타 그는 강력한 DNA 절단 약물인 calicheamicin을 돌연변이 항-CD33 단일클론항체인 gemtuzumab에 하이드라존 결합 
(hydrazone bond)을 포함하는 절단형 링커로 결합시킨 것이 다. 이 $\mathrm{ADC}$ 는 약물 항체 비율(drug-to-antibody ratio, DAR) 값이 평균 1.5 이며, $50 \%$ 정도의 결합되지 않은 항체와 섞 인 혼합물이다. 세포에 들어간 후 하이드라존 결합은 엔 도솜의 산성 환경에서 가수분해되어 calicheamicin의 전 구체가 방출되는데 글루타치온에 의해 환원되어 자유형 의 calicheamicin으로 전환된다. Calicheamicin은 DNA의 부 홈(minor groove)에 결합한 후 고도의 활성 래디칼(radical) 을 만든 후 DNA 이중가닥을 절단한다. 이론적으로 하이 드라존은 혈류의 생리적 $\mathrm{pH}$ 에서 안정적이고 세포 내재화 후 종양세포의 산성 환경에서만 선택적으로 가수분해 되 지만, 실제로는 혈장순환 중 미리 방출되어 심한 독성을 보였다. 2017년에 재승인될 때에는 용량을 낮추고 투여 간격을 조정하였다(Joubert et al., 2020).

2017년에 화이자의 베스폰사(Besponsa $\left.{ }^{\circledR}\right)$ 가 급성림프구 성백혈병(Acute lymphocytic leukemia, ALL) 치료 용도로 승인되었다. 여기에서도 마일로타그에서 사용된 링커와 유사한 링커가 calicheamycin을 항-CD22 IgG4, 단일클론항 체에 연결하는 데 사용되었다(Jabbour et al., 2021).

\section{4-2. 2세대 비절단 링커 ADC; 캐싸일라(Kadcyla $\left.{ }^{\circledR}\right)$}

미국 이뮤노젠(ImmunoGen)사는 글루타치온 감응성 이 황화 결합(disulfide bond)을 이용하여 maytansine 유도체를 결합시키는 링커 개발에 집중하였다. 암세포의 세포질에 는 혈장보다 글루타치온의 농도가 1,000 배 가량 더 높아 서 통제된 방출을 기대할 수 있기 때문이다. 이 과정에서 제넨텍(Genentech)과 로슈(Roche)에서 승인받은 캣싸일라 의 개발이 이루어졌다. 캣싸일라에서는 항암약물인 DM1 (Mertansine; Maytansinoid DM1)을 항-HER2 단클론항체의 라이신 잔기에 비절단 링커인 heterobifunctional thioether 링커로 결합시켰는데, 세포 내재화 후에만 약물이 효소적 으로 절단되었으며, HER2 양성 유방암에 강력한 효과를 나타냈다(Barginear et al., 2013).

이 방식의 $\mathrm{ADC}$ 는 생리적 $\mathrm{pH}$ 에서 전하를 띄고 있어서 주변세포살상 작용이 없었다. 이 비절단 링커는 항원을 보유한 표적세포에만 선택적으로 작용하고 정상세포에서 는 독성이 제한적이며, 혈류에서 링커는 절단되지 않았다 (Joubert et al., 2020).

\section{4-3. 2세대 절단 링커 ADC: 애드세트리스(Adcetris ${ }^{\mathbb{\circledR}}$ ),} 폴라이비(Polivy $\left.{ }^{\mathbb{R}}\right)$, 패드세프(Padcev $\left.{ }^{\mathbb{R}}\right)$

한편 시에틀제네틱스(Seattle Genetics)사는 치료약물로 dolastatin 유도체인 MMAE (monomethyl auristatin E)를 선 택하여 항-CD30 단일클론항체의 시스테인 잔기에 연결 시키는 링커를 설계하여 애드세트리스를 개발하였다. 항 -CD30 단클론항체의 이황화 결합을 부분적으로 환원시킨 후 절단 링커인 heterobifunctional maleimide 링커(ValCit$\mathrm{PAB}$ linker)에 결합시켰다. 이 링커는 리소좀의 cathepsin $\mathrm{B}$ 에 감응성인 valine-citrulline 펩티드를 가지고 있어서 $\mathrm{CD} 30$-양성 암세포에 내재화된 후 MMAE가 방출되어 표 적 암세포를 살상하게 된다.

애드세트리스는 2011년 역형성대세포림프종과 호지킨 림프종을 적응증으로 승인되었다. 링커가 절단된 후 방출 된 MMAE는 표적세포를 파괴하고 세포막을 통과하여 주 변의 암세포도 살상하므로 비균질성 림프종도 치료하는 효과를 보였다(Katz et al., 2011).

이 2세대 링커로 항암약물 MMAE를 항-CD79b 항체에 연결한 것이 제넨텍과 로슈에서 개발한 폴라이비이다. 폴 라이비는 미만성 큰 B세포 림프종 병용치료제로 2019년 에 승인되었다. 플라이비의 평균 DAR 값은 3.5 이다(Deeks, 2019)

시에틀제네틱스와 아스텔라스(Astellas)에서 개발한 패드 세프는 같은 링커를 사용하였는데, 종전에 항-PD1/PDL1 항체로 치료를 받았던 전이성 요로상피세포암 환자를 적응 대상으로 하여 2019년 승인되었다(McGregor and Sonpavde, 2019).

\section{4-4. 3세대 ADC; 트로델비(Trodelvy $\left.{ }^{\circledR}\right)$ 엔허투(Enhertu $\left.{ }^{\circledR}\right)$, 블렌렙(Blenrep ${ }^{\circledR}$ ), 진론타(Zynlonta $\left.{ }^{\circledR}\right)$}

최근 승인된 새로운 3 세대 $\mathrm{ADC}$ 에서는 개선된 세포독 성약물과 새로운 링커가 사용되었다.

이뮤노메딕스(Immunomedics)는 트로델비(Trodelvy)를 개 발하는데 약간 과발현된 표적을 타겟팅을 하고, 종전의 $\mathrm{MMAE}$ 나 DM1과 같은 약물보다 더 독성이 약한 약물을 채택하고, 약물이 세포 내부 및 세포 외부에서 모두 방출 이 되게 하였다. 2020년 US FDA에서 승인을 받은 트로델 비(Trodelvy)에서는 항-TROP2 단일클론항체에 세포독성약 물로서 topoisomerase I 억제제인 SN-38을 polyethylene glycol (PEG)로 붙인 절단형 maleimide 링커를 사용하였다. 트로델비는 2번 이상 치료이력이 있는 재발성, 난치성 전 이 3 중 음성 유방암을 적응증으로 승인되었는데, 이 분야 는 기존 치료제가 없는 미충족의료수요 영역이다. 링커에 $\mathrm{PEG}$ 를 도입하여 $\mathrm{DAR}$ 을 7.6까지 올렸다(Goldenberg and Sharkey, 2020). 
다이이치산쿄(Daiichi Sankyo)는 엔허투(Enhertu)의 개발 에 SN-38보다 암세포에서 10 배 정도 활성이 높은 세포독 성약물인 DXD (exatecan)를 사용하였다. $\mathrm{DXD}$ 는 용해성이 좋고 비교적 안전하며 주변세포살상효과가 높아서 비균 질종양의 치료에 이점이 있다. 그러나 오프타겟 효과를 줄일 수 있는 위한 반감기는 짧다. DXD는 항-HER2 항체 의 시스테인 잔기에 maleimide 링커로 생접합되었는데 균 질 $\mathrm{DAR}$ 값이 8 에 달한다. 높은 $\mathrm{DAR}$ 값에도 불구하고 $\mathrm{DXD}$ 가 혈장에서 21 일 동안 단 $2.1 \%$ 만 방출되었을 정도 로 안정성이 높다(Ogitani et al., 2016). 엔허투는 2019년 $\mathrm{US} \mathrm{FDA}$ 에서 허가를 받았는데 대상 환자는 과거 2번 이 상 HER2 표적치료를 받은 전력이 있는 절제 불가능한 전이성 Her2 양성 유방암 성인 환자이다(Keam, 2020).

글락소스미스클라인(GlaxoSmithKline, GSK)은 다발성골 수종 ADC 신약인 블렌렙(Blenrep)을 2020년 승인받았다. 블렌렙은 항-B세포성숙화항원(B-cell maturation antigen, $\mathrm{BCMA}, \mathrm{CD} 38$ ) 단일클론항체 $\mathrm{ADC}$ 로서, 프로테아좀 억제 제, 면역조절제를 포함해 최소 네 가지 이상의 치료를 받 은 재발성 또는 불응성 다발성골수종 성인 환자의 단독 요법으로 승인받았다. 블렌렙은 전 세계에서 최초로 승 인된 항-BCMA 치료제이다. 블랜렙은 약 4 개의 $\mathrm{MMAF}$ 분자를 항-BCMA 단일클론항체의 시스테인 잔기에 비절 단 protease-저항성 maleimidocaproyl 링커를 이용하여 접 합시켜 놓았다(Tai et al., 2014). 블랜렙은 여러 가지 기전 으로 암세포를 제거하는데, $\mathrm{MMAF}$ 의 살상효과에 더하여 항체 의존 세포독성, 항체 의존 식세포작용 등이 관여한 다(Markham, 2020)

미국 생명공학기업 $\mathrm{ADC}$ 테라퓨틱스(ADC Therapeutics) 는 항-CD19 단일클론항체 ADC인 진론타를 2021년 5월 에 승인받았다. 진론타는 두 가지 이상의 전신요법을 받 은 성인의 재발성 또 불응성 $(\mathrm{r} / \mathrm{r})$ 거대 $\mathrm{B}$ 세포 림프종으로 적응증을 인정받았다. 이 승인에는 달리 명시되지 않은 미만성 거대 $\mathrm{B}$ 세포 림프종, 저등급 림프종 및 고등급 $\mathrm{B}$ 세포 림프종에서 발생한 미만성 거대 $\mathrm{B}$ 세포 림프종도 포함된다. 진론타는 세포독성약물로 pyrrolobenzodiazepine (PBD) 이합체를 최초로 채택하였다. 약 2.3 분자의 $\mathrm{PBD}$ 이 합체가 cathepsin $\mathrm{B}$ 로 절단되는 발린-알라닌 링커로 항체 에 결합되어 있다. 약물이 방출되면 DNA 부홈에서 두 가 닥 간 교차결합을 형성하여 표적세포를 죽인다(Dean et al., 2021; Mullard, 2021)

\section{5. 세계적으로 임상시험 중인 $\mathrm{ADC}$ 현황}

Daen 등의 보고서에 의하면, 2021년 6월 말 기준으로 $\mathrm{US} \mathrm{FDA}$ 에서 승인된 11개 $\mathrm{ADC}$ 품목은 (Table 1) 모두 종양과 관련된 적응증으로 허가되었다. 같은 시점에서 80 개 이상의 $\mathrm{ADC}$ 기반 치료제가 다양한 종양을 치료하 기 위한 목적으로 단독 혹은 병용으로 임상시험을 진행 중이다. 임상시험 중인 $\mathrm{ADC}$ 대부분은 임상I상, 혹은 임 상I/II 상에 있다. 약 $80 \%$ 는 고형종양에 대하여 안전성과 효력시험 단계에 있으며, 나머지는 혈액암과 관련이 있다. 근래 패드세프와 트로델비와 같은 $\mathrm{ADC}$ 의 성공적인 개발 에 힘입어, 전체 $\mathrm{ADC}$ 임상시험 중 고형암에 대한 임상시 험의 비중이 점차 커지는 경향이 보인다(Dean et al., 2021)

전세계에서 진행되고 있는 임상시험을 총망라하고 있 는 미국 'NIH의 ClinicalTrials.gov' site에서 2021년 8월 15일 자로 'antibody drug conjugate'라는 키워드로 현재시점에서 $\mathrm{ADC}$ 임상시험 진행 현황을 조사하였다. 검색조건으로는 recruitment, eligibility criteria, study type, study results, study phase, fund type, study documents를 모두 'all'로 하였다. 등 록된 $\mathrm{ADC}$ 관련 임상시험의 총 건수는 316 건으로 나타났 는데, 80 여개 $\mathrm{ADC}$ 품목이 여러 지역에서 여러 가지 적응 증으로 중복하여 진행되고 있는 것으로 보인다. $\mathrm{ADC}$ 임 상건수를 'On map'으로 지역별로는 분류하였을 때, 미국 247건, 유럽 85건, 동아시아 61건, 캐나다 45건, 태평양 32 건, 일본 21 건, 중동 15 건, 러시아 14 건 등으로 나타났 다. 전통적으로 바이오제약산업이 강한 북미와 유럽이 $\mathrm{ADC}$ 임상시험에서 중심적인 위치를 차지하고 있었다. Table 2는 임상시험 적응증(condition)을 중심으로 하는 'topic'으로 분류하여, 질환 condition별 임상건수에서 빈도 가 높은 것을 추출한 것이다. 대부분의 임상시험은 종양 에 대하여 시행되고 있으며, 가장 대표적인 임상 대상 질 환으로는 유방신생물 67건, 비뇨생식기신생물 48건, 호 지킨병 46건, 폐신생물 38건 등이었다(ClinicalTrials.com, 2021).

\section{ADC 개발에서 고려해야할 요소들}

$\mathrm{ADC}$ 를 설계할 때에는 타겟 종양세포에 대한 특이성을 강화하고 혈장에서의 안정성을 확보하여 정상세포에 대 한 독성을 줄이면서 효율적인 약물을 채택하여 종양세포 살상효과를 높이는 것이 중요하다. 이를 위해서는 $\mathrm{ADC}$ 
Table 2. Numbers of clinical trials of ADCs by clinical conditions (extracted from the data by ClinicalTrial.gov. as of Aug. 15th, 2021) (ClinicalTrial.gov., 2021)

\begin{tabular}{lc}
\hline \hline \multicolumn{1}{c}{ Conditions } & Studies \\
\hline Adenocarcinoma & 26 \\
Breast Neoplasms & 67 \\
Carcinoma Bronchogenic & 19 \\
Digestive System Neoplasms & 24 \\
Endocrine Gland Neoplasms & 24 \\
Gastrointestinal Neoplasms & 24 \\
Genital Neoplasms, Female & 24 \\
Genital Neoplasms, Male & 13 \\
Head and Neck Neoplasms & 13 \\
Hodgkin Disease & 46 \\
Kidney Neoplasms & 14 \\
Leukemia & 33 \\
Lung Neoplasms & 38 \\
Multiple Myeloma & 20 \\
Neuroectodermal Tumors & 13 \\
Ovarian Neoplasms & 25 \\
Pancreatic Neoplasms & 10 \\
Prostatic Neoplasms & 15 \\
Stomach Neoplasms & 11 \\
Thoracic Neoplasms & 25 \\
Urogenital Neoplasms & 48 \\
\hline
\end{tabular}

의 기본적인 구조(Fig. 1)를 형성하는 항체, 세포독성약물, 이를 접합시키는 링커, 접합 방법 등이 모두 중요한 고려 요소가 된다.

\section{6-1. 표적 항원(target antigens)}

$\mathrm{ADC}$ 에서 항체와 표적 항원의 상호작용은 안전성을 확 보하고 치료효과를 얻는데 중요하다. 항원선택의 두 변 수는 종양특이성과 발현수준이다. 이상적으로는 항원이 종양에서만 특이적으로 발현되고, 정상세포에서는 발현이 없거나 최소화되는 것이다. 특이성은 독성을 줄이는데 결 정적이며 $\mathrm{ADC}$ 의 성공을 좌우한다. 암 특이 항원은 종양 세포의 표면에서 표면 수용체로 발현되거나 종양혈관계 통, 종양미세환경 내부에서 발현된다. 균질 종양에서처 럼 암 특이 항원이 종양조직에서 균질하게 발현되어서 모든 암세포가 약물에 반응하면 암의 치료가 쉬워진다. 비균질 종양의 경우 반응을 하지 않는 암세포가 섞여 있 어서 $\mathrm{ADC}$ 치료 후에도 살아남는 암세포가 존재할 수 있
다. $\mathrm{ADC}$ 가 주변세포살상효과를 가지고 있다면 이러한 비 균질 종양의 문제를 극복할 수 있다(Damelin et al., 2015).

$\mathrm{ADC}$ 에 사용되는 단일클론항체로는 $\mathrm{IgG} 1, \mathrm{IgG} 2, \mathrm{IgG} 4$ 가 사용되는데 이중 $\mathrm{IgG1}$ 이 가장 많이 사용된다. 전통적 인 $\mathrm{ADC}$ 에서는 온전한 전체 크기의(full length) 항원이 사 용되었다. 흡수와 투과를 증진시키기 위한 전략으로 보다 작은 $\mathrm{Fab}, \mathrm{scFv}$, diabody를 단일클론항체 대신 사용하는 것 이 시도되고 있지만 아직은 검증과 개선이 필요하다 $(\mathrm{Li} \mathrm{et}$ al., 2019).

현재 임상시험 중인 $\mathrm{ADC}$ 중에서 뛰어난 시장성으로 인해 매력적으로 사용되는 표적 항원은 HER2로 알려져 있으며 3 개의 $\mathrm{HER} 2$ 표적 $\mathrm{ADC}$ 가 임상 3 상 단계에 있다 (Dean et al., 2021).

종양세포에 내부화된 항원을 표적으로 삼는 것은 세포 내 기질이 풍부한 고형종양에서 쉽지 않은 일이다. 이러 한 경우 암세포보다 종양미세환경을 표적으로 삼아 접근 한다. 세포 외 단백질이나 세포 외 기질의 산성물질이나 글루타치온과 같은 성분을 이용하여 세포독성약물을 세 포 외에서 방출한다(Joubert et al., 2020).

\section{6-2. 세포독성약물(cytotoxic drugs, payloads)}

항체는 $\mathrm{ADC}$ 의 효과를 결정하는데 있어서 중요한 구성 물로 여겨지지만 종양세포살상을 집행하는 것은 바로 세 포독성약물이다. 세포독성약물은 종양세포의 살상을 유 도하는 저분자 약물(small molecule drugs)이다. $\mathrm{ADC}$ 에 사 용되는 세포독성약물은 미세소관 파괴 약물과 DNA 변형 약물이 주종을 이룬다. 미세 소관이 파괴되면 세포 분열 단계에 있는 세포가 사멸한다. DNA 변형 제제는 세포주 기와 상관없이 세포를 죽일 수 있다. 근래에 이와 다른 개 념의 세포독성약물들도 개발되어 사용되고 있다(Shin et al., 2018).

\section{6-2-1. 미세소관 파괴 약물(tubulin disrupter)}

가장 많이 사용되는 미세소관 파괴 약물(tubulin disrupter, antimitotic)은 auristatin 계열이다. Monomethyl auristatin E (MMAE, 일명 vedotin)이라 불리는 세포독성약물은 강력 한 미세소관 중합 억제제이다. 이 약물은 애드세트리스 와 폴라이비같은 $\mathrm{ADC}$ 에서 dipeptide 링커에 연결되어 cathepsin $\mathrm{B}$ 효소에 의해 항체에서 절단되어 방출되도록 고 안되었다. 다른 유도체인 monomethyl auristatin F (MMAF) 도 미세소관의 중합을 억제하며, 비분해성 링커에 결합되 어 세포 방출이 제한된 형태로 개발되었다. MMAF는 블 
렌렙에서 사용되었다. 다른 미세소관 억제제로 maitansine 이 있는데 튜불린에 붙어서 미세소관의 조립을 억제한 다. Maitansine의 유도체는 maytansinoid라 불리며 DM1, $\mathrm{DM} 2, \mathrm{DM} 4$ 등이 있는데, 캣싸일라에서는 DM1이 사용되 었다. 다른 미세소관 억제제로는 tubulysins, cryptomycins, antimitotic EG45 억제제 등이 연구되고 있다(Kostova et al., 2021).

\section{6-2-2. DNA 변형(DNA damaging) 약물}

암세포는 빠르게 분열하므로 DNA 변형(DNA damaging) 약물도 암세포 제거에 효과적이다. DNA 변형 제제는 강력한 효력을 가지므로 $\mathrm{ADC}$ 에 적용하면 약물의 부작 용을 줄이고 효력은 높일 수 있다. DNA 변형 제제로는 calicheamicin, pyrrolobenzodiazepine (PBD), SN-38, DXD (exatecan 유도체), camptothecin (CPT)과 그 유도체 등이 있다.

Calicheamicin은 DNA 부홈에 결합한 다음 DNA 이중가 닥을 잘라낸다. Calicheamicin은 마일로타그에서 사용되었 다. $\mathrm{PBD}$ 이량체는 $\mathrm{DNA}$ 부홈에 결합하여 교차 공유결합 을 만들어 $\mathrm{DNA}$ 의 복제를 억제하여 암세포를 사멸시킨다. $\mathrm{PDB}$ 는 현재 임상시험에 많이 적용되고 있으며, 2021년에 승인된 진론타에 사용되었다.

\section{6-2-3. 기타 세포독성(cytotoxic) 약물}

$\mathrm{SN}-38$ 은 DNA 이소머라제 I (DNA topoisomerase I)을 저해하여 세포분열을 막는다. 기존에 사용된 약물에 비하 여 효력이 낮아서 부작용이 적으며 $\mathrm{DAR}$ 을 높여서 $\mathrm{ADC}$ 의 부작용 대비 효력을 높이는데 사용될 수 있다. SN-38 은 트로델비에 사용되었다. DXD는 SN-38보다 암세포에 서 10 배 정도 활성이 높은 $\mathrm{DNA}$ 이소머라제 I 억제제로 서 엔허투에 사용되었다(Kostova et al., 2021).

현재 임상시험 중인 일부 $\mathrm{ADC}$ 는 세포독성약물로 tolllike receptor 7/8 (TLR 7/8) 작용약(agonist)을 사용한다. TLR $7 / 8$ 이 자극되면 인터페론과 다른 사이토카인이 많이 생산 되어서, 결과적으로 자연살상세포와 세포독성 $\mathrm{T}$ 세포가 활 성화되어 암세포를 파괴한다(Frega et al., 2020).

다른 세포독성약물로는 RNA polymerase II 억제제인 amatoxin 유도체인 amanitin 종류가 있다. 현재 임상시험 중인 $\mathrm{ADC}$ 에서 사용되고 있는데, 이 약물은 전사과정을 억 제하여 단백질 합성을 막고 세포사멸을 유도한다(FigueroaVazquez et al., 2021).

세포자멸사(apoptsis) 경로를 타겟팅하여 세포사멸을 유
도하는 것도 좋은 암치료법이 된다. BCL-2 패밀리 단백질 은 미토콘드리아 중재성 세포자멸사에 중심적인 역할을 한다. 이중 anti-apoptotic 단백질인 BCL-2, BCL-XL, MCL-1 은 잘 알려진 항암 타겟이다. $\mathrm{BCL}-\mathrm{XL}$ 을 타겟으로 하는 약물이 $\mathrm{ADC}$ 에 적용되어 임상시험이 진행 중이다(Zhang et al., 2020).

\section{6-3. 링커(linkers)}

링커는 $\mathrm{ADC}$ 에서 항체와 약물을 결합시킨다. 바람직한 링커는 혈류에서는 안정적면서 표적 암세포에서는 약물 을 적절히 방출하여 약물을 표적에 안전하게 전달하는 것이다. $\mathrm{ADC}$ 플랫폼의 개발에서 링커는 중요한 역할을 한다. 링커로 약물을 항체에 결합할 때, 약물이 항체의 구 조적 안정성과 기질 결합특성과 약물동태에 영향을 주지 않아야 한다. 초창기 $\mathrm{ADC}$ 약물이 실패한 원인 중의 하나 는 약물의 조기 방출로 알려져 있다. 새로운 링커들이 개 발되면서 신규 $\mathrm{ADC}$ 제제는 과거에 비해 안전하고 약효 도 높다.

현재 임상시험 중인 상당수의 $\mathrm{ADC}$ 는 hydrazone, disulfide, peptide 또는 thioether 결합 등 화학적 링커를 채택 하고 있다. 링커에서 약물을 방출하는 과정은 암세포 내 의 특정한 $\mathrm{pH}$ 나 효소 농도 등의 차이를 이용한다. 보통 hydrazone과 disulfide 링커는 혈장 내에서 안정성이 제한 되어 있다. 반면 펩타이드 기반의 링커는 혈장 내 안정성 이 우수하고 약물 방출 조절도 용이하다(Shin et al., 2018).

일부 화학적 링커는 항체와 약물의 소수성(hydrophobicity)의 균형을 조절하여 친수성 환경인 혈류 내에서 $\mathrm{ADC}$ 의 응집을 방지한다. 친수성 링커와 스페이서(spacer) 에는 cyclodextrin, polyethylene glycol (PEG) 또는 다른 중 합체가 있는데, 혈류 내의 안정성과 약물동력학적 특성에 역할을 한다.

$\mathrm{ADC}$ 에 사용된 링커는 절단능력에 따라 비절단성과 절 단성으로 나누어진다.

\section{6-3-1. 비절단형 링커(non-cleavable linkers)}

비절단성 링커는 상대적으로 높은 혈장 안정성을 가지 고 있으며 단백질분해에 저항적이다. 세포 내에 도입된 후 항체가 분해되어야 약물이 링커와 복합체 형태로 방 출되는데 이 복합체가 약물활성을 가진다. Thioether 링 커는 대표적인 비절단형 링커인데, 단일클론항체가 세포 내에서 비선택적으로 분해된 후에 약물이 이탈하여 방출 되도록 한다. 캐싸일라 $\left(\mathrm{Kadcyla}^{\circledR}\right)$ 가 비절단형 방식을 채택 
하고 있다.

\section{6-3-2. 절단형 링커(cleavable linkers)}

절단형 링커는 특정 환경요소에 반응하여 절단되어 약 물을 세포질로 방출한다. 절단형에는 효소 절단형과 비효 소 절단형이 있다.

효소 절단형은 cathepsin $\mathrm{B}, \beta$-glucuronidase, phosphatase, pyrophosphatase, sulfatase와 같은 효소에 의해 절단된다. Peptide 링커는 단백질 분해효소에 의해 분해되며, 혈 장 내에서는 단백질 분해효소 억제제가 존재하여 혈장 안정성이 높다. $\mathrm{ADC}$ 에 이용되는 단백질 분해효소로는 cathepsin $\mathrm{B}$ 가 대표적이다. Cathepsin $\mathrm{B}$ 는 종양조직에서 높은 수준으로 존재하여 $\mathrm{ADC}$ 에게 종양 선택성을 준다. Peptide 링커는 주로 아미노산 두 개를 붙인 dipeptide로 개발되고 있으며 애드세트리스(Adcetris $\left.{ }^{\circledR}\right)$ 에 적용되었다. $\beta$-glucuronide 링커는 리소좀 내에 존재하는 당분해효소인 $\beta$-glucuronidase에 의해 분해된다. $\beta$-glucuronidase는 일부 종 양세포에서 과발현되어 종양 특이성을 준다.

비효소 절단형에는 산 불안정 링커(acid-labile linker)와 산화환원반응 링커(oxidation-reduction reaction linker)가 있 다. 산 불안정 링커는 초창기에 개발된 안정성이 비교적 낮은 링커이지만 아직도 사용되고 있다. 대표적인 것이 hydrazone 링커로 종양세포에 내재화 된 후 엔도좀, 리소 좀의 약산성 환경에서 가수분해 되어 약물을 방출한다. 산화화원반응 링커는 disulfide 링커가 대표적이다. 내재화 된 후 이황화 교환이나 glutathione과 같은 환원제에 의해 링커가 분해되면서 세포독성약물을 방출한다. Glutathione 은 저산소상태인 종양세포에서는 정상세포보다 약 1,000 배 정도 농도가 높아서 $\mathrm{ADC}$ 에 종양세포 선택성을 부여 한다(Hong et al., 2021; Kostova et al., 2021).

\section{6-4. 접합 방법(conjugation methods)}

지금까지 출시된 $\mathrm{ADC}$ 들은 불균질한 혼합물들로서 항 체 위에서 약물의 결합위치가 여러 군데이고 결합된 약 물의 수도 불규칙하다. 약물-링커 복합체가 항체에 접합 되는 위치는 약물의 안정성과 약물동태학-약물동력학적 특성에 영항을 준다. $\mathrm{ADC}$ 제조과정에서 약물이 항체에 붙는 비율인 DAR을 통제하기 어려웠었다. DAR이 높으면 혈장에서 청소(clearance)가 빨라지고, DAR이 낮으면 치료 효과가 낮았다. 또한 DAR이 불균질하게 섞여 있는 $\mathrm{ADC}$ 에서는 투여 후에 DAR이 낮은 항체가 DAR이 높은 항체 와 경쟁하여 $\mathrm{ADC}$ 의 효과를 감소시켰다. 이러한 문제를
해결하기 위하여 위치특이적인 결합 방법이 개발되었다. 위치특이인 방법에서는 $\mathrm{ADC}$ 의 구조와 균질성을 유지하 면서, 약물을 항체의 특정한 위치에 선택적으로 결합시 키고, 결합되는 약물의 수를 엄격하게 조절할 수 있게 한다. 위치특이적인 결합 방법에는 크게 자연적인 항체 (native antibody)를 사용하는 방법과 공학적으로 개량된 항 체(engineered antibodies)를 사용하는 두 가지 방법이 있다.

\section{6-4-1. 자연적인 항체(native antibody)를 수식하여} 위치특이적으로 생접합(bioconjugation) 하는 방법

자연적인 항체를 사용하는 것은 인공 항체를 만들 때 생기는 복잡한 돌연변이 항체 선별과정이나 배양 최적화 과정을 피할 수 있어서 편리한 방법이다. 항체에 내재적 인(endogenous) 라이신, 히스티딘, 티로신, 시스테인 잔기 등에 접합시킨다. 2021년까지 승인된 모든 $\mathrm{ADC}$ 는 이 내 재적인 아미노산 잔기를 접합에 사용하였다. 번역후가공 과정에서 $\mathrm{Fc}$ 지역에 글리칸(glycan)을 삽입한(incorporated) 자연적인 항체도 사용되었다. $\mathrm{IgG}$ 는 원래 당단백질이므로 각 중쇄의 N-297번 위치에 N-glycan이 존재한다. 이 글리 코실(glycosyl) 자리에 링커-약물 복합체를 접합시킬 수 있다(Zhou, 2017).

전통적인 방법에서는 항체의 라이신 잔기와 시스테인 잔기에 약물을 결합시켰다. 항체에는 라이신 잔기가 여 러 군데에 많이 있어서 라이신을 쓰는 방법은 불균질성 (heterogeneity)을 피하기 어려웠다. 최근 대부부의 $\mathrm{ADC}$ 는 이황화 결합 시스테인 인터체인(interchain disufide cysteine) 을 접합목적으로 사용한다. 시스테인 접합의 경우 항체 내에 시스테인의 숫자가 적어서 균질성이 좋아질 뿐만 아니라 DAR의 조절도 용이하게 하였다(Dean, 2021). 라이 신과 히스티딘 잔기의 경우 불균질성 문제를 극복하기 위하여 화학적인 방법으로 항체에서 특정한 하나의 라이 신 잔기나 히스티딘 잔기만을 수식하여 위치특이성을 확 보하는 방법도 개발되었다(Kostova et al., 2021).

6-4-2. 공학적으로 가공된 항체(engineered antibody)를 사용하여 위치특이적으로 생결합(bioconjugation) 하는 방법

공학적 항체는 $\mathrm{DAR}$ 을 다루기가 용이하여 이 방법으로 하면 보다 균질한 $\mathrm{ADC}$ 를 만들기 쉽다. 자연적인 혹은 인 공적인 아미노산 잔기를 항체의 특정 위치에 넣어서 약 물동태학-약물동력학적 특성을 좋게 할 수 있다.

먼저 효소적인 방법이 있는데, 항체에 유전공학적으로 
삽입한 아미노산 $\operatorname{tag}$ 를 이용하여 약물을 고도로 선택적 으로 접합시킬 수 있다. 이 tag는 formylglycine-generating enzyme (FGE), microbial transglutaminase (MTG), sortase, 혹 은 tyrosinase와 같은 효소가 특이적으로 인식하여 위치 특이적인 접합을 가능하게 한다. SMARTag ${ }^{\circledR}$ 이라 불리는 방법에서는 위치특이적인 접합을 위하여 aldehyde tag를 붙였다. 단일클론항체의 특정 부위에 있는 시스테인에 aldhyde인 formylglycine을 붙여서 이곳에 접합을 하도록 한다(Jain et al., 2015).

두 번째로는 시스테인 공학적인 방법이 있는데, $\mathrm{Thiomab}^{\circledR}$ 기술은 이황화 결합에 참여하지 않은 공학적으 로 삽입된 시스테인을 이용하여 위치특이적으로 결합하 여 균질성을 확보해준다. Tiomab ${ }^{\circledR}$ 기술은 항-MUC16 단 일클론항체에서 처음 보고되었는데 중쇄의 116번 알라닌 을 시스테인 잔기로 유전공학적인 방법으로 치환하였다 (Junutula et al., 2008).

또 다른 방법은 비정규 아미노산을 항체에 넣어 위치 특이적인 접합을 하게 하는 것이다. 이때 삽입되는 인공 아미노산은 약물-링커 혼합체가 선택적으로 접합이 되도 록 독특한 화학 구조를 가진 것으로 한다. 비정규 인공 아미노산은 면역원성을 일으킬 수도 있어서 유의해야 하 는데, lysine의 cyclopropene 유도체, selenocysteine과 같은 것들이 사용되었다(Kostova, 2021).

\section{6-5. 약물 항체 비율(drug-to-antibody ratio, DAR)}

약물항체 비율인 $\mathrm{DAR}$ 은 $\mathrm{ADC}$ 개발에서 약물동태학적 특성과 생체 내 분포를 결정하는 매우 중요한 특성이다. $\mathrm{DAR}$ 이 높을 $\mathrm{ADC}$ 일수록 in vitro 시험에서는 효능이 높 게 나왔다. 그러나 정작 높은 $\mathrm{DAR}$ 을 가진 $\mathrm{ADC}$ 가 기대 와 달리 생체 내 효능이 낮게 나오는데, 그 이유는 결합 된 약물이 많은 $\mathrm{ADC}$ 일수록 혈장 청소율이 높기 때문인 것으로 추정되었다. 이에 따라 한동안 $\mathrm{ADC}$ 제제의 $\mathrm{DAR}$ 은 2 4 정도로 맞추어 왔다.

소수성(hydrophobicity)으로 인한 문제도 존재한다. 주로 사용되는 상당수의 세포독성약물과 링커가 소수성이다. 이 때문에 $\mathrm{ADC}$ 가 응집하거나, 표적 항원에 대한 친화력 을 상실하거나, 혈장 청소율이 높아지는 등의 문제가 발 생한다. Sulfonate 혹은 polyethylene glycol (PEG)을 함유한 친수성 링커는 소수성 링커로 인한 문제점을 해결해준다. PEG 링커는 수용성이며, 독성이 낮고 또한 면역원성이 낮 은 장점이 있다.

$\mathrm{DAR}$ 이 4 정도가 최적이라고 오랫동안 생각해왔었는데
사실 이는 MMAE나 DM1을 약물로 쓰는 2세대 링커에 해당되는 경우이며 3 세대 링커에서는 DAR이 높은 것이 더 좋다고 한다(Joubert et al., 2020; Shin et al., 2018). 근래에 승인된 $\mathrm{ADC}$ 는 $\mathrm{DAR}$ 값이 거의 8에 달하는 것이 많으며, 현재 임상시험 중인 신규 $\mathrm{ADC}$ 들은 $\mathrm{DAR}$ 값이 1에서 15 까지 다양하다고 한다(Dean et al., 2021).

\section{7. 글로벌 빅파마 바이오제약사의 $\mathrm{ADC}$ 진출 현황}

제약업종 시장조사분석기관인 이밸류에이트파마(Evaluate Pharma)에 따르면, 글로벌 $\mathrm{ADC}$ 치료제 시장 규모는 2019년 27억달러에서 2026년 248억달러로 성장할 것으로 전망된다. 연평균 $37 \%$ 로 성장을 하여 7 년 만에 시장 규 모가 무려 9배 이상으로 팽창할 전망이다(Evaluate pharma, 2020).

$\mathrm{ADC}$ 신약이 $\mathrm{US} \mathrm{FDA}$ 에서 연이어 승인되고 있고, $\mathrm{ADC}$ 의 미래 전망이 한층 밝아지자 글로벌 제약사들이 $\mathrm{ADC}$ 치료제 개발에 경쟁적으로 진출하고 있다. 세계적인 거대 제약사들은 $\mathrm{ADC}$ 를 개발하는 제약회사나 $\mathrm{ADC}$ 에 특화되 어 있는 바이오기업에 투자하거나 이를 인수하는 전략적 인 제휴 관계를 맺어서 $\mathrm{ADC}$ 시장에 진입하고 있다. 최근 에 일어난 $\mathrm{ADC}$ 와 관련된 빅딜은 다음과 같다.

2020년 7월 영국 아스트라제네카(AstraZeneca plc)가 일 본 다이이찌산쿄(Daichi Sankyo)의 ADC 후보물질인 DS162 에 대해 총 60 억달러 규모의 공동 개발 계약을 체결 했다. DS-162는 Trop-2에 특이적인 항체에 약물을 결합한 $\mathrm{ADC}$ 이며 미일 양국에서 비소세포암과 유방암에 대하여 임상시험을 진행 중이다(Yoo, 2020).

2020년 9월 미국 제약사 길리어드 사이언스(Gilead Sciences)는 미국의 바이오기업 이뮤노메딕스(Immunomedics)를 약 210 억달러에 인수하였다. 길리어드는 이를 통 해 이뮤노메딕스의 $\mathrm{ADC}$ 치료제를 보유하게 되어 바이 오의약품 시장의 지배력을 높였다. 앞서 이뮤노메딕스 (Immunomedics)는 2020년 4월 US FDA에서 트로델비를 유방암 치료제로 승인받았다(Jang, 2020).

2020년 9월 미국 MSD (Merck Sharp \& Dohme)는 미국 시애틀 제네틱스(Seattle Genetics)와 ADC 유방암 치료제를 공동 개발한다고 발표했다. MSD가 시애틀 제네틱스에 계 약금으로 6 억달러, 단계별로 기술료로 최대 26억달러를 지급하는 계약이다. 별도로 10 억달러 상당의 지분투자도 포함되어 총 42 억달러에 달하는 대규모 투자이다. 두 회 
사는 유방암과 기타 종양 두 가지에 대해 임상 2상을 단 계인 $\mathrm{ADC}$ 치료 후보물질 '라디라투주맙 베도틴'을 공동 으로 개발하여 상용화한다(Lee, 2020).

2021년 6월 미국 브리스톨마이어스스퀴브(BMS)는 일 본 에자이(Eisai)와 고형종양 $\mathrm{ADC}$ 를 개발하기 위해 협력 관계를 맺었다. $\mathrm{ADC}$ 인 $\mathrm{MORAb}-202$ 을 공동으로 개발하고 공동으로 상업화하는 글로벌 전략적 제휴이다. MORAb202 는 에자이가 자체 개발한 항체인 항-엽산 수용체 알파 $(\mathrm{FR} \alpha)$ 항체에 항암제인 에리불린(eribulin)을 효소 절단형 링커로 결합한 것이다. $\mathrm{BMS}$ 는 에자이에게 연구개발 비용 2 억 달러를 포함해 6억 5000만 달러를 지급하며, 향후 개 발, 승인, 상업적 이정표의 달성에 따라 최대 24억 5000만 달러를 추가로 지불하기로 했다(Park, 2021).

\section{8. 국내 바이오제약업계의 $\mathrm{ADC}$ 개발 현황}

$\mathrm{ADC}$ 가 최근 안전성과 효과 측면에서 검증이 되고 성공 가능성이 높아지자 국내 기업들도 $\mathrm{ADC}$ 시장의 선점을 위해 경쟁에 뛰어들고 있다. 바이오벤처뿐만 아니라 일부 제약 대기업에서도 $\mathrm{ADC}$ 치료제 개발 대열에 참여하고 있다.

앱티스는 $\mathrm{ADC}$ 개발에 전문화된 기업으로 자체 개발한 링커 플랫폼 기술인 $\mathrm{AbClick}^{\circledR}$ 을 보유하고 있다. $\mathrm{AbClick}^{\circledR}$ 기술에서는 항체에 아미노산을 삽입하거나 교체하는 변 이과정이 없이 광조사만으로 세포독성약물을 항체의 특 정 라이신에 선택적으로 결합시킨다. 이 기술은 $\mathrm{DAR}$ 을 쉽게 조절할 수 있으며, 항체의 특정 부위에 변이를 일으 키지 않기 때문에 적용분야가 넓다. 앱티스는 이 플랫폼과 신규 항체를 이용해 위암, 삼중음성유방암 및 비소세포폐 암 등에 대한 신약후보물질을 개발하고 있다(Lee, 2020).

인투셀은 $\mathrm{ADC}$ 개발 기업으로 오파스 링커(ortho hydroxyprotected aryl sulfate $\left(\mathrm{OHPAS}^{\circledR}\right)$ linker)라는 고유의 링커를 보유하고 있다. 다른 링커는 주로 아민(amine)기를 가진 약물만을 연결할 수 있지만 $\mathrm{OHPAS}^{\circledR}$ 는 페놀(phenol)류 약 물에도 연결할 수 있다. 페놀기는 다양한 약물류가 가지 고 있어서 여러 분야의 약물을 손쉽게 연결할 수 있다. 따라서 항암제뿐만 아니라 다른 질환 치료 연구에도 응용 이 될 가능성이 높다(Hong, 2020).

레고켐바이오사이언스는 ConjuALL ${ }^{\circledR}$ 이라는 자체 $\mathrm{ADC}$ 플랫폼 기술을 개발하였는데, 잠재력을 인정받아 다수의 해외 빅파마에 라이센싱 되었다. ConjuAll ${ }^{\circledR}$ 플랫폼은 위치 특이적인 접합을 통해 특정 부위에만 링커와 약물이 결합
될 수 있다. 링커가 우수하여 혈중 안정성이 높고 타겟에 서 약물을 효과적으로 방출한다. 또한 결합약물로 기존 $\mathrm{PBD}$ toxin의 한계를 극복한 PBD prodrug toxin을 가지고 있다(Bae, 2019). ConjuALL ${ }^{\circledR}$ 은 위치특이적인 접합 기술을 통해 DAR을 2 혹은 4로 일정하게 조절한다. ConjuALL ${ }^{\circledR}$ 의 링커는 절단형 링커로 선택성이 높다. 레고켐바이오는 익수다테라퓨틱스와 2020년 2건을 계약했고 2021년에는 타겟을 3 개에서 6개로 확장하였다(Choi, 2021).

바이오시밀러의 세계적인 강자인 항체 바이오의약품 기 업인 셀트리온도 $\mathrm{ADC}$ 분야에 진출하였다. 셀트리온은 캐 나다 아이프로젠(iProgen Biotech)과 4종의 $\mathrm{ADC}$ 신약개 발을 진행 중이다. 셀트리온의 항체 기술과 아이프로젠 의 $\mathrm{ADC}$ 플렛폼 기술, $\mathrm{ADED}^{\circledR}$ 를 결합시켰다. 셀트리온은 2021년 영국 ADC 기업 익수다 테라퓨틱스(Iksuda Therapeutics)에도 지분 투자 형태로 협력을 시작했다(Seo, 2021). 알테오젠은 자체 개발한 $\mathrm{NexMab}^{\circledR}$ 기술을 기반으로 하 여 난소암 치료제로 사용할 항체를 개량해 결합력을 높 인 신규항체를 개발했다. 이 항체로 $\mathrm{ADC}$ 난소암 치료제 ALT-Q5를 개발할 예정이다. 이 항체는 난소암세포 표면 에 존재하는 FOLR1 (folate receptor alpha)에 특이적으로 결합하여 FOLR1의 활성을 차단한다 $(\mathrm{Ha}, 2021)$.

한미약품은 레고켐바이오와 협력을 통해 이중항체 $\mathrm{ADC}$ 항암제를 개발하고 있다. 북경한미가 개발한 이중항체 플 랫폼인 펜탐바디를 적용하는데, 펜탐바디는 하나의 항체 가 서로 다른 2 개의 표적에 동시에 결합하여, 단일항체 로 접근이 어려운 암종에 효과가 있을 것으로 기대된다 (Hwang, 2021).

이중항체 전문기업인 에이비엘바이오도 $\mathrm{ADC}$ 플랫폼 을 개발하고 있다. 에이비엘바이오는 독성항암제를 기존 방식과 다르게 항체의 $\mathrm{N}$-말단에 붙였다. 이 NTERM (Nterminal selective conjugation method, $\mathrm{NTERM}^{\circledR}$ ) 방법은 기 존의 $\mathrm{ADC}$ 방식에 비해 안정적이며 독성 부작용이 낮아 치료용량범위를 확장시켰다. 에이비엘바이오는 또한 레고 켐바이오와 협력관계를 통하여 자신의 이중항체 플랫폼 에 레고켐바이오의 $\mathrm{ADC}$ 기술을 접목하여 항암제 LCB71 을 개발하고 있다(Kim, 2021)

\section{9. 논의}

$\mathrm{ADC}$ 는 기존 항암화학요법의 강항 독성 문제를 해결해 줄 것이라는 기대로 출발했다. 초창기에 승인된 $\mathrm{ADC}$ 항 암제들은 항암효과를 높이면 독성이 심해지고, 반대로 안 
전성을 높이면 항암효과가 충분히 발휘되지 못해 치료영 역이 좁아지는 난관이 있었다. 그러나 새로운 기술이 등 장하면서 $\mathrm{ADC}$ 약물의 치료영역이 넓어지고, 종양 반응 율도 높아지고 있다.

세포독성약물 payload 부분에서 개선이 많이 이루어지 고 있다. 새로운 기전의 $\mathrm{ADC}$ 용 세포독성약물이 다양하게 개발되고 있다. 과거에는 효능을 높이기 위해 세포독성 효 과가 높은 약물을 사용했으나, 근래에는 독성이 낮은 약 물을 사용하고, DAR를 높이려는 경향이 나타난다.

연구의 관심이 전달성이 우수한 링커에도 쏠리고 있다. 링커는 혈류 내에서는 약물을 꽉 잡아 안정성이 높고, 표 적세포에서는 정확하게 방출되어 정밀성이 높아야 한다. Mersana Therapeutics 사의 경우 특수한 화학링커를 이용해 15 개 이상 톡신을 전달하는 $\mathrm{ADC}$ 플랫폼 기술을 Takeda 와 함께 개발 중이다. Sorrento Therapeutics 등 다른 여러 기업도 새로운 기전의 $\mathrm{ADC}$ 용 링커를 개발 중이다. 독특 한 링커를 개발하면 독점적인 물질특허를 확보할 수 있 는 장점도 있다(Kim, 2018).

세계적으로 다양한 $\mathrm{ADC}$ 제제의 임상시험 연구가 진행 되고 있다. 초창기에 비해서 $\mathrm{ADC}$ 제제가 적용되는 적응 증이 확대되고 있다. $\mathrm{ADC}$ 는 주로 항암제로 개발되었지만 최근에는 면역이나 감염증에도 적용하는 연구가 진행되고 있다(Jun, 2020).

암을 치료하는 데 선택할 수 있는 항암제는 여러 가지 가 있다. 그러나 단독요법으로 극적인 효과를 볼 수 있는 항암제는 그리 많지 않기 때문에 두 가지 이상을 섞어서 쓰는 병용요법이 많이 연구되고 있다. $\mathrm{ADC}$ 는 항암화학요 법과 표적항암제의 장점을 동시에 가진 특성으로 인하여 면역관문 억제제와의 병용요법제로 개발될 가능성도 있 다. 많은 $\mathrm{ADC}$ 가 면역관문 억제제와의 병용요법에 대한 파트너로의 개발되고 있다.

새로운 $\mathrm{ADC}$ 제제들은 새로운 개념의 약물을, 새로운 타겟팅 항체에, 새로운 링커로 결합하여 만들어진다. 세계 의 $\mathrm{ADC}$ 회사들은 새로운 세포독성약물, 새롭고 다양하고 안정적인 링커, 새로운 위치특이적 생접합 기술 등의 기반 기술을 개발하고 있다. $\mathrm{ADC}$ 개발을 위한 툴박스 속에 새 롭고 유용한 연장들이 하나씩 채워지고 있다. 항체공학 기술이 발달하여 다양한 항원에 대한 항체도 확보되어 적 용할 수 있는 타겟도 확장되고 있다. 선택할 수 있는 툴 박스 속의 연장이 많아지면서 $\mathrm{ADC}$ 로 촉망되는 신약을 개발할 수 있는 여건이 무르익어가고 있다(Bae, 2019).

종양은 개별화된 질환이라 일컬어질 만큼 유전적으로
복잡하고 다양하다. 각 종양의 분자생물학적 기전에 따라 서 접근을 세분화하여 종양별로 최적의 약물, 링커, 항체, 접합기술 등을 조합할 수 있을 것이다. 맞춤의학 시대에 걸맞는 다양한 $\mathrm{ADC}$ 기반 치료제가 개발되어서 앞으로 각 종 암을 치료하고 미충족의료수요를 해결하는데 기여할 것을 기대한다.

\section{ACKNOWLEDGEMENT}

None.

\section{CONFLICT OF INTEREST}

The author certifies that I have no affiliations with or involvement in any organization or entity with any financial interest or non-financial interest in the subject matter or materials discussed in this manuscript.

\section{REFERENCES}

Bae JJ. The history of Artillery is repeated. ADC, The anticancer drugs loaded with warheads. MediGate News. 2019. 4. 12.

Barginear MF, John V, Budman DR. Trastuzumab-DM1: a clinical update of the novel antibody-drug conjugate for HER2overexpressing breast cancer. Mol Med. 2013. 18: 1473-1479.

Biochempeg, Worldwide PEG Supplier home page. 11 FDA approved ADC, An overview. (https://www.biochempeg.com /article/74.html) as of 2021.8.15.

Choi SJ. The reason why LegoChemBio is a must-go-restaurant of Bio Industry. PharmNews. 2021. 3. 22.

ClinicalTrials.com. https://www.clinicaltrials.gov/ as of 2021. 8. 15.

Damelin M, Zhong W, Myers J, Sapra P. Evolving Strategies for Target Selection for Antibody-Drug Conjugates. Pharm Res. 2015. 32: 3494-3507.

Dean AQ, Luo S, Twomey JD, Zhang B. Targeting cancer with antibody-drug conjugates: Promises and challenges. MAbs. 2021. 13: e1951427(23 pages).

Deeks ED. Polatuzumab Vedotin: First Global Approval. Drugs. 2019. 79: 1467-1475.

Evaluate pharma 2020. https://www.evaluate.com/thought-leadership /vantage/evaluate-vantage-2021-preview.

Figueroa-Vazquez V, Ko J, Breunig C, et al. HDP-101, an AntiBCMA Antibody-Drug Conjugate, Safely Delivers Amanitin to Induce Cell Death in Proliferating and Resting Multiple Myeloma Cells. Mol Cancer Ther. 2021. 20: 367-378. 
Frega G, Wu Q, Le Naour J, et al. Trial Watch: experimental TLR7 /TLR8 agonists for oncological indications. Oncoimmunology. 2020. 9: 1796002.

Goldenberg DM, Sharkey RM. Sacituzumab govitecan, a novel, third-generation, antibody-drug conjugate (ADC) for cancer therapy. Expert Opin Biol Ther. 2020. 20: 871-885.

Ha SJ. Alteogen, developing ovarian cancer drug, ALT-Q5 with ADC biobetter technology. Health In News. 2021. 7. 6.

Hammood M, Craig AW, Leyton JV. Impact of Endocytosis Mechanisms for the Receptors Targeted by the Currently Approved Antibody-Drug Conjugates (ADCs)-A Necessity for Future ADC Research and Development. Pharmaceuticals (Basel). 2021. 14: 674

Hasan M, Alam S, Poddar SK. Antibody-Drug Conjugates: A Review on the Epitome of Targeted Anti-Cancer Therapy. Curr Clin Pharmacol. 2018. 13: 236-251.

Hong ST. Intocell, ADC, Drug linked with linker technology, kills cancer cells selectively. HelloDD. 2020. 12. 28.

Hong YD, Kang KG, Jung JY, Ha SJ, Lim KS. Antibody-drug conjugates: Development and advances. Korean Soc for Biotech \& Bioeng J. 2021. 36: 87-98.

Hwang JJ. K-bio develops Drug + antibody, the next generation new drug ADC. Economic Review. 2021. 7. 30.

Jabbour E, Paul S, Kantarjian H. The clinical development of antibody-drug conjugates - lessons from leukaemia. Nat Rev Clin Oncol. 2021. 18: 418-433.

Jang YS. Gilead tries to merge US Immunomedics at 230 billion dollars. ChosunBiz. 2020. 9. 13.

Jain N, Smith SW, Ghone S, Tomczuk B. Current ADC Linker Chemistry. Pharm Res. 2015. 32: 3526-3540.

Joubert N, Beck A, Dumontet C, Denevault-Sabourin C. AntibodyDrug Conjugates: The Last Decade. Pharmaceuticals (Basel). 2020. 13: 245

Jun SM. antibody drug market, Watch immunocytokine-ADC therapy. selective effect on cancer cells. Yakup.com. 2020. 10 21.

Junutula JR, Raab H, Clark S, et al. Site-specific conjugation of a cytotoxic drug to an antibody improves the therapeutic index. Nat Biotechnol. 2008. 26: 925-932.

Katz J, Janik JE, Younes A. Brentuximab Vedotin (SGN-35). Clin Cancer Res. 2011. 17: 6428-6436.

Keam SJ. Trastuzumab Deruxtecan: First Approval. Drugs. 2020. 80: 501-508.

Kim MK. Trends for Antibody-drug Conjugates for Therapy). Biochemistry and Molecular Biology News. 2011. 31: 43-52.
Kim MK. The key of next generation ADC platform is linker. The linker determines efficacy and toxicity. DailyPharm. 2018. 9. 18.

Kim SM. ABLBio improved half-life and toxicity with ADC plarform NTERM ${ }^{\circledR}$. BioSpectator. 2021. 4. 48.

KoBIA (Korea Biomedicine Industry Association). Global biopharmaceutical market trend. Biopharmaceutical industry. 2021. as of 2021.8.8https://www.kobia.kr/sub01/sub01_2.php

Kostova V, Désos P, Starck JB, Kotschy A. The Chemistry Behind ADCs. Pharmaceuticals (Basel). 2021. 14: 442.

Lee HK. MSD reinforces to collaborate with Seattle Genetics on anticancer drugs. Medical News. 2020. 9. 15.

Lee YJ, Toward the unicons.. Selection of the first baby 40 unicons. Doctor's News. 2020. 6. 30.

Li Z, Li Y, Chang HP, Chang HY, Guo L, Shah DK. Effect of Size on Solid Tumor Disposition of Protein Therapeutics. Drug Metab Dispos. 2019. 47: 1136-1145.

Markham A. Belantamab Mafodotin: First Approval. Drugs. 2020. 80: 1607-1613.

McGregor BA, Sonpavde G. Enfortumab Vedotin, a fully human monoclonal antibody against Nectin 4 conjugated to monomethyl auristatin E for metastatic urothelial Carcinoma. Expert Opin Investig Drugs. 2019. 28: 821-826.

Mullard A. FDA approves ADC Therapeutics' loncastuximab tesirine, ushering in a new cytotoxic payload. Nat Rev Drug Discov. 2021. 20: 414.

Ogitani Y, Aida T, Hagihara K, et al. DS-8201a, A Novel HER2Targeting ADC with a Novel DNA Topoisomerase I Inhibitor, Demonstrates a Promising Antitumor Efficacy with Differentiation from T-DM1. Clin Cancer Res. 2016. 22: 5097-5108.

Park BJ. ADC. the war searching optimum combination of antibodylinker-payload. Health Care Herb Hit News. 2021. 7. 27.

Seo YS. Celltrion invests 47 million dollars to Iksuda Therapeutics to have ADC. BioSpectator. 2021. 6. 7.

Shin SH, Park MH, Byeon JJ, et al. Market Trends of antibodydrug conjugate and its new platform technologies. Yakhak Hoeji, 2018. 62: 158-170.

Su D, Zhang D. Linker Design Impacts Antibody-Drug Conjugate Pharmacokinetics and Efficacy via Modulating the Stability and Payload Release Efficiency. Front Pharmacol. 2021. 12: 687926.

Tai YT, Mayes PA, Acharya C, et al. Novel anti-B-cell maturation antigen antibody-drug conjugate (GSK2857916) selectively induces killing of multiple myeloma. Blood. 2014. 123: 31283138 . 
Urquhart L. Market watch, Top drugs and companies by sales in 2017. Nature Reviews Drug Discovery. 2018. 17: 232.

Yoo JH. The war against cancer. ADC (antibody-drug conjugate) is coming. Chosun Daily. 2020. 9. 24.

Zhang X, Liu X, Zhou D, Zheng G. Targeting anti-apoptotic BCL2 family proteins for cancer treatment. Future Med Chem. 2020. 12: 563-565.

Zhou Q. Site-Specific Antibody Conjugation for ADC and Beyond.
Biomedicines. 2017. 5: 64.

https://doi.org/10.15616/BSL.2021.27.3.121

Cite this article as: Kwon SI. Market Trend and Current Status of the Research and Development of AntibodyDrug Conjugates. Biomedical Science Letters. 2021. 27: 121-133. 